\title{
Pertumbuhan dan Hasil Sorgum di Tanah Latosol dengan Aplikasi Dosis Pupuk Nitrogen dan Fosfor yang Berbeda
}

\section{Sorghum Growth and Yield in Latosol Soil with Different Level of Nitrogen and Phosphorus Applications}

\author{
Ratna Suminar $^{1}$, Suwarto $^{2 *}$, dan Heni Purnamawati ${ }^{2}$ \\ ${ }^{1}$ Program Studi Agronomi dan Hortikultura, Sekolah Pascasarjana, Institut Pertanian Bogor \\ ${ }^{2}$ Departemen Agronomi dan Hortikultura, Fakultas Pertanian, Institut Pertanian Bogor \\ (Bogor Agricultural University), Jl. Meranti, Kampus IPB Darmaga, Bogor 16680, Indonesia
}

Diterima 6 April 2017/Disetujui 31 Oktober 2017

\begin{abstract}
Sorghum (Sorghum bicolor L. Moench) is prospective crop for food as well as feed and bioenergy. It adapts to wide agroclimate and agroecology. However, the productivity is accounted low in Indonesia. Low productivity of sorghum can be enhanced through intensification, e.g., precise dose of nitrogen and phosphorus fertilizers application. The aim of this research was to determine the optimum dose of nitrogen and phosphorus fertilizers to maximize growth and yield of sorghum in latosol soil, in order to develop fertilizer recommendation on specific soil type. The research was conducted at Cikarawang, Bogor from March to July 2015. Nitrogen and phosphorus fertilizers were arranged and applied simultaneously using randomized completely block design with three replications. Nitrogen fertilizer was applied in five levels, i.e., 0, 60, 120, $180,240 \mathrm{~kg} N$ $\mathrm{ha}^{-1}$ and phosphorus levels were 0, 18, 36, 54, $72 \mathrm{~kg} \mathrm{P}_{2} \mathrm{O}_{5} \mathrm{ha}^{-1}$. Results showed that the application of nitrogen and phosphorus fertilizers significantly increased vegetative growth and yield components. The optimum dose were $161 \mathrm{~kg} \mathrm{~N} \mathrm{ha-1} \mathrm{(133.7 \% )}$ and $43 \mathrm{~kg} \mathrm{P}_{2} \mathrm{O}_{5} \mathrm{ha}^{-1}(121.5 \%)$ for latosol soil.
\end{abstract}

Keywords: fertilizer, optimum dose, soil type, vegetative, yield component

\section{ABSTRAK}

Sorgum (Sorghum bicolor L. Moench) merupakan komoditas yang perlu mendapat perhatian karena dapat digunakan sebagai pangan, pakan dan bioenergi, dan memiliki daya adaptasi yang luas. Namun produktivitas sorgum saat ini masih tergolong rendah di Indonesia. Rendahnya produktivitas sorgum dapat ditingkatkan melalui intensifikasi, misalnya pemberian dosis pupuk nitrogen dan fosfor yang tepat. Tujuan penelitian adalah untuk menentukan dosis optimum dari pupuk nitrogen dan fosfor untuk memaksimalkan pertumbuhan hasil sorgum di tanah latosol, dalam rangka mengembangkan rekomendasi pemupukan pada jenis tanah tertentu. Penelitian dilaksanakan di Desa Cikarawang, Kabupaten Bogor dari bulan Maret hingga Juli 2015. Percobaan $N$ dan P secara paralel masing-masing disusun menggunakan rancangan kelompok lengkap teracak dengan tiga ulangan. Setiap percobaan diterapkan dalam lima level dosis. Dosis nitrogen adalah 0, 60, 120, 180, $240 \mathrm{~kg} \mathrm{~N} \mathrm{ha-1}$ dan dosis fosfor adalah 0, 18, 36, 54, $72 \mathrm{~kg} \mathrm{P}_{2} \mathrm{O}_{5} \mathrm{ha}^{-1}$. Hasil penelitian menunjukkan penambahan dosis pupuk nitrogen dan fosfor secara nyata meningkatkan pertumbuhan vegetatif dan komponen hasil. Dosis optimum pupuk yang diperlukan adalah $161 \mathrm{~kg} \mathrm{~N} \mathrm{ha}^{-1}(133.7 \%)$ dan $43 \mathrm{~kg} \mathrm{P}_{2} \mathrm{O}_{5} \mathrm{ha}^{-1}$ (121.5\%) untuk tanah latosol.

Kata kunci: dosis optimum, jenis tanah, komponen hasil, pupuk, vegetatif

\section{PENDAHULUAN}

Indonesia berpeluang mengembangkan budidaya sorgum dengan sistem usaha terintegrasi karena besarnya manfaat yang dimiliki oleh tanaman sorgum di antaranya sebagai bahan pangan, pakan ternak, dan bahan baku industri (Irawan dan Sutrisna, 2011). Olahan biji sorgum

\footnotetext{
* Penulis untuk korespondensi. e-mail: wrtskm@yahoo.com
}

dapat digunakan sebagai beras sorgum (Suarni, 2012) dan tepung sorgum untuk mensubtitusi tepung terigu sehingga menjadi bahan pangan fungsional seperti kue kering, roti, kue, mie dan beras analog (Suarni dan Subagio, 2013). Salah satu varietas unggul nasional yang dapat digunakan adalah Numbu yang memiliki tepung berwarna putih, mudah rontok, termasuk sorgum manis, serta toleran terhadap cekaman alumunium dan defisiensi fosfor (Agustina et al., 2010; Budijanto dan Yuliyanti, 2012). 
Masalah utama peningkatan hasil sorgum adalah rendahnya produktivitas sorgum yang berada pada kisaran 1 sampai 3 ton ha $^{-1}$ dari potensi hasil yang dapat mencapai 5 ton $\mathrm{ha}^{-1}$ (Galuh et al., 2012). Salah satu usaha yang dilakukan untuk meningkatkan hasil tanaman secara intensifikasi adalah pemupukan yang tepat, spesifik lokasi berdasarkan jenis tanah. Latosol ialah jenis tanah yang banyak tersebar di Indonesia dengan luas mencapai sebesar 84.6 juta ha. Tanah latosol umumnya berada pada daerah yang beriklim basah dan memiliki karakter tanah berstruktur remah (Djaenuddin, 2009).

Nitrogen salah satu unsur makro yang diperlukan tanamanuntukmerangsang pertumbuhan akar, meningkatkan bobot akar, meningkatkan bobot kering total, meningkatkan kepekatan fosfor dalam tanaman, serta penyusun protein, klorofil, asam amino dan banyak senyawa organik lainnya (Fahmi et al., 2010). Nitrogen unsur yang mobil, mudah tercuci dan menguap sehingga ketersediaannya sering mengalami defisiensi. Selain itu, kandungan protein yang tinggi pada biji sorgum menjadikan nitrogen penting untuk penyusunan asam amino (Suarni dan Subagio, 2013).

Pemberian fosfor pada tanaman jagung di tanah latosol dapat meningkatkan pertumbuhan tanaman seperti tinggi tanaman, berat kering total, berat kering akar, dan berat kering tajuk. Gejala kekahatan unsur hara fosfor ditunjukkan gejala fisik tanaman yaitu daun berwarna keunguan (Fahmi et al., 2010).

Ketersediaan fosfor dipengaruhi kondisi tanah dan daya serap tanaman. Ketersediaan fosfor di dalam tanah dipengaruhi oleh $\mathrm{pH}$ tanah, tipe liat, temperatur, bahan organik dan waktu aplikasi (Novriani, 2010). Tanah latosol merupakan kelompok tanah yang mengalami pencucian dan pelapukan lanjut sehingga $\mathrm{P}$ pada tanah masam pada umumnya bersenyawa dalam bentuk Al-P dan Fe-P, serta Bogor merupakan daerah dengan curah hujan tinggi sehingga mengakibatkan kondisi defisiensi $\mathrm{P}$ pada tanah. Pada umumnya tanaman akan lebih peka pada kondisi defisiensi P, termasuk sorgum. Meskipun demikian, varietas sorgum memiliki tingkat toleransi yang berbeda-beda terhadap defisiensi P (Agustina et al., 2010) dan memiliki kebutuhan dosis fosfor yang berbeda pula (Marlina et al., 2015). Penelitian ini bertujuan untuk menentukan dosis optimum pemupukan nitrogen dan fosfor di tanah latosol agar pertumbuhan dan hasil sorgum sesuai dengan potensi hasilnya.

\section{BAHAN DAN METODE}

Penelitian dilaksanakan di lahan petani Desa Cikarawang, Dramaga, Bogor, sejak bulan Maret sampai Juli 2015 pada tanah latosol. Karakteristik kimia tanah latosol di lahan percobaan terdapat pada (Tabel 1). Penelitian terdiri atas dua percobaan paralel, yaitu percobaan pemupukan $\mathrm{N}$ dan $\mathrm{P}$. Masing-masing penelitian dilakukan dengan rancangan kelompok lengkap teracak faktor tunggal terdiri atas tiga ulangan dan lima dosis pemupukan yaitu 0, 50, 100, 150, dan 200\% dosis acuan. Dosis acuan 100\% adalah 120 $\mathrm{kg} \mathrm{N}$ ha-1 (Fanindi et al., 2005), $36 \mathrm{~kg} \mathrm{P}_{2} \mathrm{O}_{5} \mathrm{ha}^{-1}$, dan $90 \mathrm{~kg}$
$\mathrm{K}_{2} \mathrm{O}$ ha $^{-1}$. Nilai ini diperoleh dari beberapa hasil penelitian kemudian divariasikan menjadi taraf dosis pupuk bertingkat agar membentuk kurva kuadratik (Lumbantobing et al., 2008; Sucipto, 2010).

Tanah diolah, dibuat petakan dengan ukuran satuan percobaan $6 \mathrm{~m} \times 2 \mathrm{~m}$, lalu diberikan dolomit sebanyak 930 $\mathrm{kg} \mathrm{ha}^{-1}$ untuk mencapai $\mathrm{pH} 6.5$ dan diinkubasi 2 minggu. Benih sebanyak 4 butir varietas Numbu ditanam dengan jarak tanam $75 \mathrm{~cm} \times 25 \mathrm{~cm}$. Setelah tumbuh dipertahankan 2 tanaman per lubang dan ditaburkan karbofuran ke dalam lubang. Pembumbunan dilakukan saat 30 hari setelah tanam (HST). Pengendalian gulma secara manual dan pengendalian burung menggunakan jaring dan alat pengusir burung yang menghasilkan bunyi. Panen dilakukan pada saat biji malai sorgum bernas dan keras.

Pupuk $\mathrm{N}$ diberikan sesuai perlakuan pada percobaan pupuk $\mathrm{N}$, dan $\mathrm{K}$ sebanyak $90 \mathrm{~kg} \mathrm{~K}_{2} \mathrm{O}$ ha $^{-1}$ yang diberikan tiga tahap, yaitu $40 \%$ dosis saat tanam, $30 \%$ dosis saat 30 HST dan 45 HST. Pupuk P diberikan $100 \%$ pada saat tanam sebanyak $36 \mathrm{~kg} \mathrm{P}_{2} \mathrm{O}_{5}$ ha $^{-1}$.

Pemupukan $\mathrm{P}$ sesuai perlakuan diberikan satu tahap, yaitu $100 \%$ saat tanam untuk percobaan pemupukan $P$. Setiap perlakuan diberikan pupuk dasar $\mathrm{N}$ dan $\mathrm{K}$ sebanyak $120 \mathrm{~kg} \mathrm{~N} \mathrm{ha}^{-1}$ dan $\mathrm{K}_{\text {sebanyak }} 90 \mathrm{~kg} \mathrm{~K}_{2} \mathrm{O} \mathrm{ha}^{-1}$ yang diberikan dengan tiga tahap yaitu $40 \%$ dosis saat tanam, $30 \%$ dosis saat 30 HST dan $30 \%$ dosis saat 45 HST.

Peubah yang diamati meliputi tinggi tanaman, diameter batang, jumlah daun, indeks luas daun, kadar hara N, P, K daun, bobot basah brangkasan per tanaman, bobot kering brangkasan per tanaman, produktivitas dan bobot biji per tanaman. Data yang diperoleh diolah dengan analisis ragam dan jika hasil pengujian menunjukkan perbedaan nyata antar perlakuan, maka dilanjutkan dengan uji lanjut kontras

Tabel 1. Hasil analisis tanah awal di lahan Cikarawang

\begin{tabular}{lcl}
\hline Sifat tanah & Nilai uji tanah & Status \\
\hline $\mathrm{pH}$ & 5.50 & Masam \\
$\mathrm{C}$-organik (\%) & 1.99 & Rendah \\
$\mathrm{N}(\%)$ & 0.24 & Sedang \\
$\mathrm{C} / \mathrm{N}$ & 8.00 & Rendah \\
$\mathrm{P}_{2} \mathrm{O}_{5}$ Bray (ppm) & 18.20 & Sangat tinggi \\
$\mathrm{K}_{2} \mathrm{O}$ Morgan (ppm) & 100.00 & Sangat tinggi \\
$\mathrm{KTK}$ & 11.35 & Rendah \\
$\mathrm{Ca}\left(\mathrm{me} 100 \mathrm{~g}^{-1}\right)$ & 5.53 & Rendah \\
$\mathrm{Mg}\left(\mathrm{me} 100 \mathrm{~g}^{-1}\right)$ & 1.87 & Sedang \\
$\mathrm{K}\left(\mathrm{me} 100 \mathrm{~g}^{-1}\right)$ & 0.20 & Rendah \\
Na (me $\left.100 \mathrm{~g}^{-1}\right)$ & 0.01 & Sangat rendah \\
Kejenuhan basa (\%) & 67.00 & Tinggi \\
Pasir $(\%)$, & 2.00 & \\
Debu (\%), & 91.00 & \\
Liat (\%) & 7.00 & \\
\hline
\end{tabular}

Keterangan: Status kondisi tanah (Balai Penelitian Tanah, 2005) 
polinomial ortogonal dan uji DMRT (Duncan Multiple Range Test) pada taraf $\alpha 0.05$.

\section{HASIL DAN PEMBAHASAN}

\section{Analisis Tanah dan Kondisi Umum}

Hasil analisis tanah sebelum penelitian menunjukkan tingkat kesuburan tanah pada lahan percobaan tergolong sedang. Berdasarkan data iklim yang diperoleh dari Badan Meteorologi, Klimatologi dan Geofisika Stasiun Klimatologi Darmaga Bogor, penelitian dilaksanakan pada musim kering dengan jumlah curah hujan bulanan kurang dari $200 \mathrm{~mm}$. Suhu, kelembaban udara dan intensitas penyinaran matahari mingguan rata-rata berturut-turut sebesar $25-27{ }^{\circ} \mathrm{C}, 75-85 \%$ dan 328.06 kalori $\mathrm{cm}^{-2}$ per hari. Menurut Hardjowigeno dan Widiatmaka (2007) sorgum dapat tumbuh baik dengan syarat tumbuh yang diperlukan suhu rata-rata $25-30{ }^{\circ} \mathrm{C}$, curah hujan tahunan 600-2000 mm, kelembapan udara 75-85\% sehingga kondisi selama penelitian masih dalam keadaan normal dan mendukung pertumbuhan dan perkembangan sorgum (Gambar 1).

\section{Tinggi Tanaman dan Diameter Batang}

Penambahan dosis $0-240 \mathrm{~kg} \mathrm{~N}$ ha $^{-1}$ meningkatkan tinggi tanaman sebesar $22 \%$ dan diameter batang sebesar $42 \%$ (Tabel 2). Tinggi tanaman meningkat sejalan dengan meningkatnya dosis pupuk dengan pola respon linier sedangkan untuk diameter batang adalah kuadratik. Tanaman sorgum yang diberi pupuk $180 \mathrm{~kg} \mathrm{~N}$ ha $^{-1}$ memiliki pertumbuhan terbaik dibandingkan perlakuan pupuk nitrogen lainnya. Peningkatan tinggi tanaman dan diameter batang diduga berasal dari hasil asimilasi/fotosintat yang ditranslokasikan ke meristem ujung untuk menghasilkan selsel baru di ujung batang. Ketersediaan N yang cukup pada jaringan meristem akan memicu terjadinya pembelahan, perpanjangan dan pembesaran sel untuk membentuk dinding sel dan protoplasma (Made, 2010).

Rata-rata tinggi tanaman sorgum yang mendapat perlakuan pupuk $\mathrm{N}$ lebih pendek dibandingkan dengan tanaman yang mendapat perlakuan pupuk P (Tabel 2). Hal ini mengindikasikan bahwa unsur $\mathrm{N}$ lebih dibutuhkan dan mungkin merupakan faktor pembatas saat fase pertumbuhan tanaman sorgum pada tanah latosol. Unsur pembatas pertumbuhan tanaman sorgum pada tanah latosol dapat berbeda dengan jenis tanah lainnya. Hal ini sejalan dengan pernyataan Fahmi et al. (2010) bahwa pertumbuhan jagung di tanah regosol dibatasi oleh unsur $\mathrm{P}$ dan di tanah latosol dibatasi oleh unsur $\mathrm{N}$.

Penambahan dosis $\mathrm{P}_{2} \mathrm{O}_{5}$ lebih terlihat terhadap respon tinggi tanaman (Tabel 3) dibandingkan diameter batang. Perlakuan $54 \mathrm{~kg} \mathrm{P}_{2} \mathrm{O}_{5}$ ha $^{-1}(150 \%)$ signifikan meningkatkan tinggi tanaman dibandingkan tanaman kontrol. Perbedaan respon tanaman terhadap pemberian fosfor diduga erat kaitannya dengan peranan fosfor dalam menyediakan energi untuk pembentukan sel baru pada jaringan yang sedang tumbuh. Thompson dan Troeh (1978) menyatakan bahwa fosfat dibutuhkan oleh tanaman untuk pembentukan sel pada jaringan dan tunas yang sedang tumbuh. Hasil ini sejalan dengan penelitian Liferdi (2010) bahwa pemberian fosfor pada pertumbuhan tanaman manggis lebih terlihat pada tinggi, jumlah cabang, dan jumlah daun daripada diameter batang.

\section{Jumlah dan Indeks Luas Daun (ILD)}

Jumlah daun dipengaruhi oleh kondisi lingkungan (Syahfriani et al., 2012) sehingga perbaikan kondisi lingkungan, seperti pemupukan diharapkan meningkatkan jumlah daun. Pemberian dosis nitrogen sebanyak 0-240 kg $\mathrm{N}^{-1}$ menunjukkan respon kuadratik pada jumlah daun umur 6 dan 8 MST. Peningkatan dosis fosfor sebanyak 0-72 $\mathrm{kg} \mathrm{P}_{2} \mathrm{O}_{5} \mathrm{ha}^{-1}$ menunjukkan pola respon linier pada jumlah daun 6 MST dan ILD (Tabel 3).

Pemupukan nitrogen menunjukkan pola respon linier pada ILD (Tabel 3). ILD tertinggi ditunjukkan oleh pemberian dosis $240 \mathrm{~kg} \mathrm{~N}^{-1}$ (5.83) dan $72 \mathrm{~kg} \mathrm{P}_{2} \mathrm{O}_{5} \mathrm{ha}^{-1}$ (5.60). Nitrogen berfungsi sebagai unsur pembentuk klorofil daun, di mana daun berperan sebagai tempat berlangsungnya proses fotosintesis (Fahmi et al., 2010). Semakin banyak jumlah daun maka ILD semakin besar (Rahmawati et al., 2016) sehingga fotosintat yang dihasilkan juga lebih banyak. Turmudi (2010) menyatakan luas daun yang maksimum tidak selalu mengindikasikan bobot brangkasan dan bobot biji sorgum yang maksimum pada dosis $225 \mathrm{~kg} \mathrm{~N} \mathrm{ha}^{-1}$. Hal ini diduga bahwa peningkatan indeks luas daun merupakan upaya bentuk adaptasi tanaman agar banyak radiasi matahari yang dapat diintersepsi untuk fotosintesis dalam keadaan ternaungi (Suwarto, 2013).

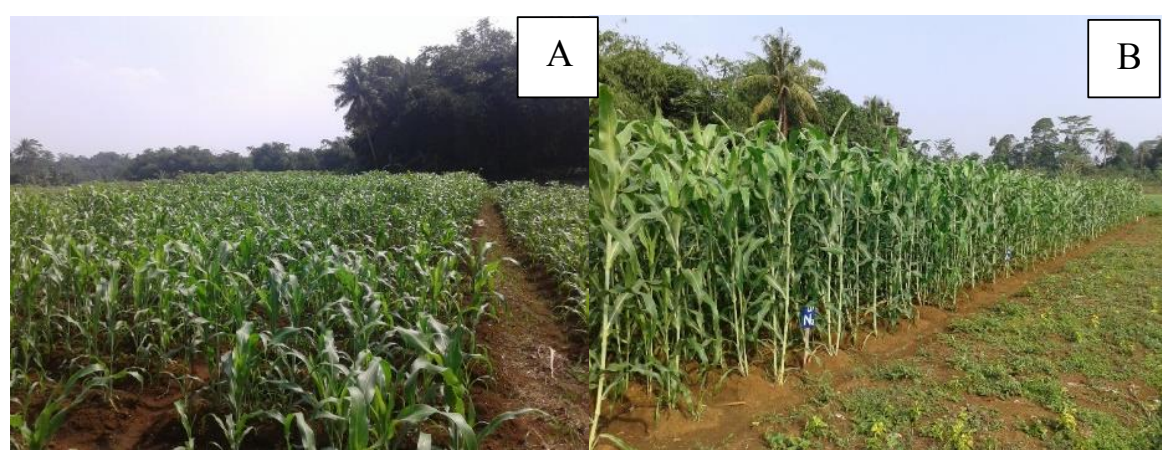

Gambar 1. Tanaman sorgum di lahan umur 43 hari setelah tanam (HST) (A) dan 52 HST (B) 
Tabel 2. Pertumbuhan tinggi tanaman dan diameter batang sorgum pada berbagai dosis pupuk

\begin{tabular}{|c|c|c|c|c|c|c|c|c|}
\hline \multirow{3}{*}{$\begin{array}{l}\text { Dosis pupuk } \\
(\%)\end{array}$} & \multicolumn{4}{|c|}{ Tinggi tanaman $(\mathrm{cm})$} & \multicolumn{4}{|c|}{ Diameter batang $(\mathrm{cm})$} \\
\hline & \multicolumn{2}{|c|}{ Percobaan N } & \multicolumn{2}{|c|}{ Percobaan $\mathrm{P}$} & \multicolumn{2}{|c|}{ Percobaan N } & \multicolumn{2}{|c|}{ Percobaan $\mathrm{P}$} \\
\hline & $\begin{array}{c}6 \\
\text { MST }\end{array}$ & $\begin{array}{c}8 \\
\text { MST } \\
\end{array}$ & $\begin{array}{c}6 \\
\mathrm{MST} \\
\end{array}$ & $\begin{array}{c}8 \\
\text { MST }\end{array}$ & $\begin{array}{c}6 \\
\mathrm{MST} \\
\end{array}$ & $\begin{array}{c}8 \\
\mathrm{MST} \\
\end{array}$ & $\begin{array}{c}6 \\
\mathrm{MST} \\
\end{array}$ & $\begin{array}{c}8 \\
\text { MST }\end{array}$ \\
\hline 0 & $125.67 \mathrm{c}$ & $196.67 \mathrm{c}$ & 165.00 & $229.33 b c$ & $0.96 \mathrm{~d}$ & $1.25 \mathrm{c}$ & $1.16 \mathrm{~b}$ & 1.58 \\
\hline 50 & $140.33 c$ & $206.33 b c$ & 162.00 & $224.00 \mathrm{c}$ & $1.17 \mathrm{c}$ & $1.51 \mathrm{~b}$ & $1.47 \mathrm{a}$ & 1.76 \\
\hline 100 & $177.00 \mathrm{ab}$ & $233.67 \mathrm{ab}$ & 169.33 & $229.00 \mathrm{bc}$ & $1.30 \mathrm{~b}$ & $1.67 \mathrm{ab}$ & $1.26 \mathrm{ab}$ & 1.60 \\
\hline 150 & $184.67 \mathrm{a}$ & $240.33 a$ & 183.33 & $244.33 \mathrm{a}$ & $1.52 \mathrm{a}$ & $1.77 \mathrm{a}$ & $1.51 \mathrm{a}$ & 1.78 \\
\hline 200 & $146.33 b c$ & $226.33 \mathrm{abc}$ & 192.33 & $240.00 \mathrm{ab}$ & $1.19 \mathrm{c}$ & $1.58 \mathrm{~b}$ & $1.44 \mathrm{a}$ & 1.66 \\
\hline Pola respon $^{\mathrm{t}}$ & $\mathrm{Q}^{* *}$ & $\mathrm{~L}^{*}$ & tn & $\mathrm{L}^{*}$ & $\mathrm{Q}^{* *}$ & $\mathrm{Q}^{* *}$ & $\mathrm{~L}^{*}$ & th \\
\hline
\end{tabular}

Keterangan: $\mathrm{t}=$ uji polinomial ortogonal terhadap dosis pupuk; $\mathrm{Q}=$ kuadratik; $\mathrm{L}=$ linier; $\mathrm{tn}=$ tidak nyata linier maupun kuadratik; * = nyata taraf $5 \% ; * *=$ nyata taraf $1 \%$, angka yang diikuti huruf yang sama pada kolom yang sama menunjukkan hasil yang tidak berbeda nyata berdasarkan DMRT pada $\alpha=5 \%$

Tabel 3. Pertumbuhan jumlah dan indeks luas daun

\begin{tabular}{lcccccc}
\hline \multirow{2}{*}{$\begin{array}{l}\text { Dosis pupuk } \\
(\%)\end{array}$} & \multicolumn{4}{c}{ Jumlah daun (helai) } & \multicolumn{2}{c}{ ILD } \\
\cline { 2 - 7 } & $6 \mathrm{MST}$ & $8 \mathrm{MST}$ & $6 \mathrm{MST}$ & $8 \mathrm{MST}$ & Percobaan N & Percobaan P \\
\hline & $7.33 \mathrm{~b}$ & $9.67 \mathrm{ab}$ & $7.67 \mathrm{~b}$ & 10.33 & $4.34 \mathrm{~b}$ & $3.93 \mathrm{bc}$ \\
50 & $7.67 \mathrm{~b}$ & $9.00 \mathrm{~b}$ & $8.67 \mathrm{ab}$ & 10.00 & $4.99 \mathrm{ab}$ & $3.48 \mathrm{c}$ \\
100 & $9.00 \mathrm{a}$ & $10.67 \mathrm{a}$ & $8.00 \mathrm{~b}$ & 10.00 & $5.33 \mathrm{a}$ & $4.57 \mathrm{abc}$ \\
150 & $9.33 \mathrm{a}$ & $10.67 \mathrm{a}$ & $9.67 \mathrm{a}$ & 10.67 & $5.28 \mathrm{a}$ & $5.17 \mathrm{ab}$ \\
200 & $8.33 \mathrm{ab}$ & $10.00 \mathrm{ab}$ & $10.00 \mathrm{a}$ & 10.00 & $5.83 \mathrm{a}$ & $5.60 \mathrm{a}$ \\
\hline Pola respon $^{\mathrm{t}}$ & $\mathrm{Q}^{*}$ & $\mathrm{Q}^{*}$ & $\mathrm{~L}^{* *}$ & tn & $\mathrm{L}^{* *}$ & L** \\
\hline
\end{tabular}

Keterangan: $\mathrm{t}=$ uji polinomial ortogonal terhadap dosis pupuk; $\mathrm{Q}=$ kuadratik; $\mathrm{L}=$ linier; $\mathrm{tn}=$ tidak nyata linier maupun kuadratik; * = nyata taraf $5 \% ; * *=$ nyata taraf $1 \%$, angka yang diikuti huruf yang sama pada kolom yang sama menunjukkan hasil yang tidak berbeda nyata berdasarkan DMRT pada $\alpha=5 \%$

\section{Kadar N, P dan K Daun}

Penambahan dosis nitrogen terhadap kadar hara $\mathrm{N}$ daun membentuk pola respon linier positif (Tabel 4). Pemberian nitrogen sebesar $240 \mathrm{~kg} \mathrm{~N}^{-1}$ menghasilkan kandungan hara $\mathrm{N}$ dan $\mathrm{P}$ daun tertinggi dibandingkan perlakuan lainnya sebesar $2.62 \%$ dan $0.37 \%$. Hal ini sesuai dengan penelitian Fahmi et al. (2010) yang menunjukkan adanya interaksi antara $\mathrm{N}$ dan $\mathrm{P}$, di mana ketersediaan $\mathrm{N}$ di tanah mempengaruhi serapan tanaman terhadap $\mathrm{P}$ dan sebaliknya.

Tabel 4. Kadar hara N, P, K daun

\begin{tabular}{lcccccc}
\hline \multirow{2}{*}{$\begin{array}{l}\text { Dosis pupuk } \\
(\%)\end{array}$} & \multicolumn{3}{c}{ Percobaan pupuk N (\%) } & \multicolumn{3}{c}{ Percobaan pupuk P (\%) } \\
\cline { 2 - 7 } & Kadar N & Kadar P & Kadar K & Kadar N & Kadar P & Kadar K \\
\hline 0 & $2.27 \mathrm{c}$ & 0.36 & $1.77 \mathrm{c}$ & $2.60 \mathrm{a}$ & $0.43 \mathrm{a}$ & $2.62 \mathrm{a}$ \\
50 & $2.43 \mathrm{~b}$ & 0.34 & $2.22 \mathrm{ab}$ & $2.33 \mathrm{c}$ & $0.41 \mathrm{a}$ & $2.36 \mathrm{~b}$ \\
100 & $2.52 \mathrm{ab}$ & 0.33 & $2.14 \mathrm{~b}$ & $2.55 \mathrm{ab}$ & $0.40 \mathrm{a}$ & $2.65 \mathrm{a}$ \\
150 & $2.56 \mathrm{ab}$ & 0.31 & $2.11 \mathrm{~b}$ & $2.47 \mathrm{~b}$ & $0.31 \mathrm{~b}$ & $2.09 \mathrm{c}$ \\
200 & $2.62 \mathrm{a}$ & 0.37 & $2.33 \mathrm{a}$ & $2.57 \mathrm{ab}$ & $0.33 \mathrm{~b}$ & $1.69 \mathrm{~d}$ \\
\hline Pola respon $^{\mathrm{t}}$ & $\mathrm{L}^{* *}$ & $\mathrm{tn}$ & $\mathrm{Q}^{* *}$ & $\mathrm{Q}^{* *}$ & $\mathrm{~L}^{* *}$ & $\mathrm{Q}^{* *}$ \\
\hline
\end{tabular}

Keterangan: $\mathrm{t}=$ uji polinomial ortogonal terhadap dosis pupuk; $\mathrm{Q}=$ kuadratik; $\mathrm{L}=$ linier; $\mathrm{tn}=$ tidak nyata linier maupun kuadratik; * = nyata taraf $5 \% ; * *=$ nyata taraf $1 \%$, angka yang diikuti huruf yang sama pada kolom yang sama menunjukkan hasil yang tidak berbeda nyata berdasarkan DMRT pada $\alpha=5 \%$ 
Penambahan dosis $0-240 \mathrm{~kg} \mathrm{~N} \mathrm{ha}^{-1}$ menunjukkan pola respon kuadratik pada kadar hara $\mathrm{K}$. Penelitian Almodares et al. (2008) menunjukkan adanya interaksi nitrogen dan kalium terhadap bobot basah tanaman. Bobot basah brangkasan merupakan indikator tingkat penyerapan air dan unsur hara oleh tanaman untuk tumbuh dan berkembang (Sutrisna et al., 2013).

Kadar hara $\mathrm{P}$ daun menunjukkan pola respon linier negatif terhadap peningkatan dosis pupuk $\mathrm{P}_{2} \mathrm{O}_{5}$. Penelitian Lestari et al. (2015) juga menunjukkan nilai kadar hara $\mathrm{P}$ daun dan biji yang semakin berkurang pada tanaman kacang bogor dengan penambahan dosis pupuk fosfor. Hal ini diduga karena kandungan $\mathrm{P}$ tersedia di dalam tanah sudah tergolong sangat tinggi sebagaimana hasil analisis tanah awal pada penelitian Lestari et al. (2015), meskipun demikian kandungannya masih dalam kecukupan batas P. Selain faktor tanah, kandungan jaringan hara tanaman juga dipengaruhi oleh jenis pupuk fosfor (Winata et al., 2014) dan varietas (Singh et al., 2012).

Kadar hara N, P dan K daun berdasarkan hasil analisis secara berturut-turut memiliki nilai $2.27-2.62 \%$, 0.31 $0.37 \%$ dan $1.77-2.33 \%$. Hasil tersebut menurut Schwab et al. (2007) menunjukkan kecukupan hara N, P, dan K pada sorgum dengan kisaran nilai berturut-turut $2.5-4.0 \%, 0.2-$ $0.35 \%$ dan $1.4-4.0 \%$.

\section{Bobot Basah, Bobot Kering Brangkasan dan Produktivitas}

Penambahan dosis pupuk nitrogen dan fosfor menunjukkan pola respon kuadratik terhadap bobot basah brangkasan dan bobot kering brangkasan (Tabel 5). Hasil penelitian menunjukkan dosis $240 \mathrm{~kg} \mathrm{~N}^{-1}$ memberikan penurunan bobot brangkasan basah dan kering setelah mencapai nilai maksimum 669.33 dan $370.00 \mathrm{~g}$ per tanaman pada dosis $180 \mathrm{~kg} \mathrm{~N} \mathrm{ha}^{-1}$. Hal ini sejalan dengan Turmudi (2010) pemberian nitrogen sebanyak $225 \mathrm{~kg} \mathrm{~N} \mathrm{ha}^{-1}$ cenderung menurunkan pertumbuhan dan produksi tanaman sorgum. Pemberian dosis nitrogen yang berlebihan dapat mengakibatkan pertumbuhan vegetatif yang berlebihan seperti daun yang dapat saling menaungi. Hal ini diduga menyebabkan proses penangkapan cahaya yang tidak optimum sehingga mempengaruhi fotosintesis. Selanjutnya, fotosintat tetap dibutuhkan oleh daun yang ternaungi untuk respirasi sehingga mengurangi fotosintat yang seharusnya untuk pengisian biji. Selain itu, Wijaya dan Soeparjono (2015) menyatakan sintesis gula menjadi terhambat karena nitrogen dipergunakan untuk sintesis $\mathrm{N}$ organik seperti pada tebu (Saccharum officinarum).

Potensi hasil varietas Numbu sebesar 5 ton ha $^{-1}$ (Sutrisna et al., 2013). Berdasarkan hasil penelitian ini diketahui bahwa semua perlakuan pemberian pupuk nitrogen nyata meningkatkan produksi biji sorgum meskipun tanpa pemberian pupuk nitrogen menghasilkan 5.90 ton ha ${ }^{-1}$ dan dengan pemberian pupuk nitrogen dapat mencapai 8.20 ton $\mathrm{ha}^{-1}$. Selanjutnya pada percobaan $\mathrm{P}$ kisaran produktivitas antara 6.00-7.70 ton ha ${ }^{-1}$. Hal ini didukung oleh kondisi tanah dengan kesuburan sedang, pemberian pupuk yang berpengaruh, dan jarak tanam yang masih cukup besar sehingga penanaman sebanyak dua tanaman per lubang masih dapat meningkatkan jumlah populasi sehingga diduga berdampak terhadap peningkatan produktivitas tanaman sorgum. Hubungan antara karakter agronomi yang memiliki korelasi positif dan nyata terhadap bobot biji yaitu diameter batang (0.620), ILD (0.340), kadar hara N (0.604), kadar hara $\mathrm{P}(0.393)$, dan kadar hara K (0.436).

\section{Bobot Biji Tanaman}

Bobot biji merupakan hasil panen berbentuk cadangan makanan yang memiliki hubungan dengan hasil metabolisme tanaman terutama fotosintesis. Hasil penelitian menunjukkan penambahan dosis nitrogen hingga $240 \mathrm{~kg} \mathrm{~N}$ ha $^{-1}$ membentuk kurva kuadratik (Gambar 2) pada peubah bobot biji per tanaman dengan nilai persamaan y $=52.067$ $+0.2577 \mathrm{x}-0.0008 \mathrm{x}^{2}$. Model ini mewakili $73.42 \%$ kondisi sesungguhnya, hasil tersebut masih dapat ditingkatkan dengan pengelolaan pemupukan yang tepat. Berdasarkan persamaan tersebut dapat ditentukan dosis pupuk nitrogen untuk mencapai bobot biji per tanaman sorgum varietas Numbu maksimum yaitu $161 \mathrm{~kg} \mathrm{~N} \mathrm{ha}^{-1}$. Penelitian Fanindi et al. (2005) menyatakan bahwa kombinasi pupuk untuk jenis Sorghum bicolor L. Moench dan Sorghum sudanense Piper Stafp yaitu 200-300 kg Urea ha-1, 100-200 kg TSP ha $^{-1}$, dan 100-300 kg KCl ha-1 dan $5000 \mathrm{~kg} \mathrm{CaCO}_{3}$ ha $^{-1}$.

Tabel 5. Komponen hasil panen tanaman sorgum

\begin{tabular}{lcccccc}
\hline \multirow{2}{*}{$\begin{array}{l}\text { Dosis pupuk } \\
(\%)\end{array}$} & \multicolumn{2}{c}{ Bobot basah brangkasan $(\mathrm{g})$} & \multicolumn{2}{c}{ Bobot kering brangkasan $(\mathrm{g})$} & \multicolumn{2}{c}{ Produktivitas $\left(\right.$ ton ha $\left.^{-1}\right)$} \\
\cline { 2 - 7 } & Percobaan $\mathrm{N}$ & Percobaan $\mathrm{P}$ & Percobaan N & Percobaan $\mathrm{P}$ & Percobaan N & Percobaan P \\
\hline 0 & $455.67 \mathrm{c}$ & $472.67 \mathrm{c}$ & $265.67 \mathrm{~b}$ & $264.67 \mathrm{~b}$ & $5.90 \mathrm{~b}$ & $6.00 \mathrm{c}$ \\
50 & $549.00 \mathrm{~b}$ & $606.33 \mathrm{ab}$ & $301.00 \mathrm{~b}$ & $333.67 \mathrm{a}$ & $6.10 \mathrm{~b}$ & $7.10 \mathrm{ab}$ \\
100 & $611.67 \mathrm{a}$ & $590.33 \mathrm{ab}$ & $359.33 \mathrm{a}$ & $310.67 \mathrm{a}$ & $7.90 \mathrm{a}$ & $6.80 \mathrm{~b}$ \\
150 & $669.33 \mathrm{a}$ & $630.33 \mathrm{a}$ & $370.00 \mathrm{a}$ & $354.33 \mathrm{a}$ & $8.20 \mathrm{a}$ & $7.70 \mathrm{a}$ \\
200 & $659.67 \mathrm{a}$ & $550.67 \mathrm{~b}$ & $354.33 \mathrm{a}$ & $332.67 \mathrm{a}$ & $7.00 \mathrm{ab}$ & $6.60 \mathrm{bc}$ \\
\hline Pola respon & $\mathrm{Q}^{*}$ & $\mathrm{Q}^{* *}$ & $\mathrm{Q}^{* *}$ & $\mathrm{Q}^{*}$ & $\mathrm{Q}^{*}$ & $\mathrm{Q}^{* *}$ \\
\hline
\end{tabular}

Keterangan: $\mathrm{t}=$ uji polinomial ortogonal terhadap dosis pupuk; $\mathrm{Q}=$ kuadratik; * = nyata taraf 5\%; ** = nyata taraf $1 \%$, angka yang diikuti huruf yang sama pada kolom yang sama menunjukkan hasil yang tidak berbeda nyata berdasarkan DMRT pada $\alpha=5 \%$ 
A

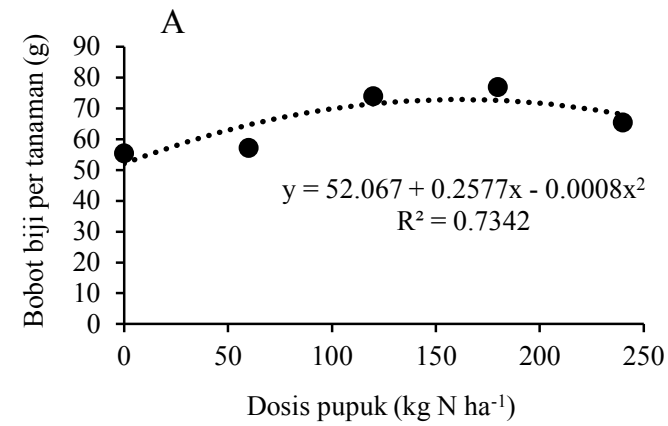

B

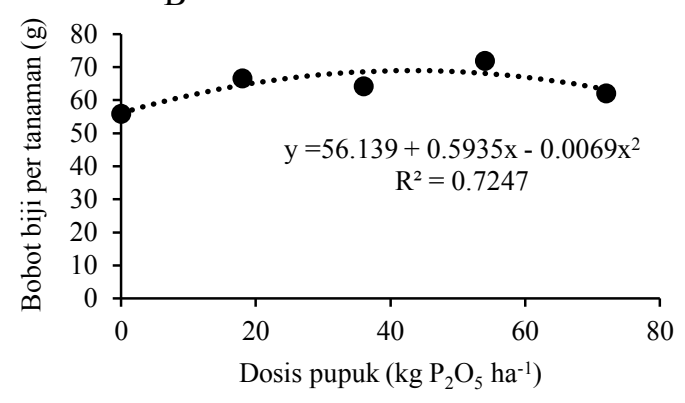

Gambar 2. Pengaruh dosis pupuk N (A) dan pupuk P terhadap bobot biji per tanaman (B)

Penambahan dosis fosfor dari $0-72 \mathrm{~kg} \mathrm{P}_{2} \mathrm{O}_{5} \mathrm{ha}^{-1}$ membentuk kurva kuadratik dengan nilai persamaan y $=$ $56.139+0.5935 x-0.0069 x^{2}$, nilai konstanta determinasi sebesar 0.7247 artinya sebesar $72.47 \%$ mewakili kondisi sesungguhnya. Berdasarkan persamaan dapat ditentukan dosis pupuk fosfor untuk mencapai bobot biji per tanaman maksimum adalah sebesar $43 \mathrm{~kg} \mathrm{P}_{2} \mathrm{O}_{5}$ ha $^{-1}$. Varietas Numbu belum bisa mewakili semua jenis sorgum. Hal ini karena sorgum memiliki kemampuan toleransi yang berbeda-beda terhadap defisiensi P (Agustina et al., 2010). Oleh karena itu penelitian spesifik lokasi dan varietas perlu terus dilakukan sehingga dapat meningkatkan kepastian hasil.

\section{KESIMPULAN}

Penambahan dosis pupuk nitrogen dan fosfor memberikan pengaruh yang berbeda nyata terhadap pertumbuhan vegetatif dan hasil biji sorgum. Dosis optimum pupuk nitrogen dan fosfor untuk pengembangan sorgum khususnya varietas Numbu di tanah latosol dengan tingkat kesuburan tanah sedang adalah $161 \mathrm{~kg} \mathrm{~N}^{-1}(133,7 \%)$ dan $43 \mathrm{~kg} \mathrm{P}_{2} \mathrm{O}_{5} \mathrm{ha}^{-1}(121,5 \%)$.

\section{UCAPAN TERIMA KASIH}

Terimakasih disampaikan kepada Direktorat Jenderal Pendidikan Tinggi untuk dana penelitiannya melalui BPPDN 2013.

\section{DAFTAR PUSTAKA}

Agustina, K., D. Sopandie, Trikoesoemaningtyas, D. Wirnas. 2010. Tanggap fisiologi akar sorgum (Sorghum bicolor [L.] Moench) terhadap cekaman alumunium dan defisiensi fosfor di dalam rhizotron. J. Agron. Indonesia 38:88-94.

Almodares, A., R. Taheri, III.M. Chung, M. Fathi. 2008. The effect of nitrogen and potassium fertilizers on growth parameter and carbohydrate contents of sweet sorghum cultivars. J. Environ. Biol. 29:849-852.

Balai Penelitian Tanah. 2005. Petunjuk Teknis Analisis Kimia Tanah, Tanaman, Air dan Pupuk. Balai
Penelitian Tanah, Departemen Pertanian, Bogor, Indonesia.

Budijanto, S., Yuliyanti. 2012. Studi persiapan tepung sorgum (Sorghum bicolor [L.] Moench) dan aplikasinya pada pembuatan beras analog. J. Teknologi Pertanian 13:177-186.

Djaenuddin, U.D. 2009. Prospek penelitian potensi sumber daya lahan di wilayah Indonesia. Pengembangan Inovasi Pertanian 2:243-257.

Fahmi, A., Syamsudin, S.N.H. Utami, B. Radjagukguk. 2010. Pengaruh interaksi hara nitrogen dan fosfor terhadap pertumbuhan tanaman jagung (Zea mays L.) pada tanah regosol dan latosol. Berita Biologi 10:297-304.

Fanindi, A., S. Yuhaeni, Wahyu. 2005. Pertumbuhan dan produktivitas tanaman sorgum (Sorghum bicolor L. Moench) dan Sorghum sudanense Piper Stafp yang mendapatkan kombinasi pemupukan N, P, K dan Ca. hal. 872-878. Prosiding Seminar Nasional Teknologi Peternakan dan Veteriner. Bogor 12-13 September 2005.

Galuh, P.N., D. Kastono, S. Waluyo. 2012. Pertumbuhan dan hasil sorgum manis (Sorghum bicolor [L.] Moench) tanaman baru dan ratoon pada jarak tanam berbeda. Vegetalika 1:11-17.

Hardjowigeno, S., Widiatmaka. 2007. Evaluasi Kesesuaian Lahan dan Perencanaan Tataguna Lahan. Gadjah Mada University Press, Yogyakarta, Indonesia.

Irawan, B., N. Sutrisna. 2011. Prospek pengembangan sorgum di Jawa Barat mendukung diversifikasi pangan. Forum Penelitian Agro Ekonomi 29:99-113.

Lestari, S.A.D., M. Melati, H. Purnamawati. 2015. Penentuan dosis pemupukan N, P, dan K pada tanaman kacang bogor (Vigna subterranea (L.) Verdcourt). J. Agron. Indonesia 43:193-200. 
Liferdi, L. 2010. Efek pemberian fosfor terhadap pertumbuhan dan status hara pada bibit manggis. J. Hort. 20:18-26.

Lumbantobing, E.L.N., F. Hazra, I. Anas. 2008. Uji efektivitas bio organic fertilizer (pupuk organik hayati) dalam mensubstitusi kebutuhan pupuk anorganik pada tanaman sweet sorghum. J. Tanah Lingkungan 10:72-76.

Made, U. 2010. Respon berbagai populasi tanaman jagung manis (Zea mays saccharata Sturt) terhadap pemberian pupuk urea. J. Agroland 17:138-143.

Marlina, E., Zuhry, Nurbaiti. 2015. Aplikasi tiga dosis pupuk fosfor pada empat varietas sorgum (Sorghum bicolor [L.] Moench) dalam meningkatkan komponen hasil dan mutu fisiologis benih. J. Online Mahasiswa 2:114.

Novriani. 2010. Alternatif pengelolaan unsur hara $\mathrm{P}$ (fosfor) pada budi daya jagung. Agronobis 2:42-49.

Rahmawati, A., H. Purnamawati, Y.W.E. Kusumo. 2016. Pertumbuhan dan produksi kacang bogor (Vigna subterranea [L.] Verdcourt) pada beberapa jarak tanam dan frekuensi pembumbunan. Bul. Agrohorti $4: 302-311$

Schwab, G.J., C.D. Lee, R. Pearce. 2007. Sampling Plant tissue for Nutrient Analysis. Lexington dan Frankfort (USA). University of Kentucky College of Agriculture dan Kentucky State University. https://www.ca.uky. edu. [6 November 2015].

Singh, M.P., J.E. Erickson, L.E. Sollenberger, K.R. Woodard, J.M.B. Vendramini, J.R. Vedenko. 2012. Mineral composition and biomassa partitioning of sweet sorghum grown for bioenergy in the southeastern USA. Biomass and Bioenergy 47:1-8.
Suarni. 2012. Potensi sorgum sebagai bahan pangan fungsional. IPTEK Tanaman Pangan 7:58-66.

Suarni, H. Subagio. 2013. Potensi pengembangan jagung dan sorgum sebagai sumber pangan fungsional. J. Litbang Pertanian 32:47-55.

Sucipto. 2010. Efektivitas cara pemupukan terhadap pertumbuhan dan hasil beberapa varietas sorgum manis (Sorghum bicolor [L.] Moench). Embryo 7:6774.

Sutrisna, N., N. Sunandar, A. Zubair. 2013. Uji adaptasi beberapa varietas sorgum (Sorghum bicolor L.) pada lahan kering di Kab Ciamis, Jawa Barat. J. Lahan Suboptimal 2:137-143.

Suwarto. 2013. Perubahan klorofil, luas daun spesifik, dan efisiensi penggunaan cahaya ubi kayu pada sistem tumpang sari dengan jagung. Bul. Agrohorti 1:135139.

Syahfriani, Taryono, Supriyanta. 2012. Efisiensi penggunaan nitrogen sepuluh kultivar sorgum manis. Vegetalika $1: 1-8$.

Thompson, L.M., F.R. Troeh. 1978. Soil and Fertility. Mc Graw-Hill Book Company, New York.

Turmudi, E. 2010. Respon pertumbuhan dan hasil tanaman sorgum terhadap frekuensi dan dosis pupuk nitrogen. J. Ilmiah Pertanian Biofarm. 13:11-24.

Wijaya, K.A, S. Soeparjono. 2015. Efek suplai nitrogen terhadap kadar gula nira tebu varietas Bululawang. J. Agritrop 13:109-112.

Winata, N.A.S.H., D.R. Lukiwati, E.D. Purbajanti. 2014. Kualitas biji sorgum manis varietas Numbu dengan pemberian sumber fosfat yang berbeda. Agrovigor $7: 63-69$. 